\title{
Development of Safety Cost for Architectural Works in Rental Apartments Building Construction Project Based on Work Breakdown Structure
}

\author{
Ditto Ferakhim, Yusuf Latief
}

\begin{abstract}
The government of Indonesia is targeting a supply shortage or housing backlog in 2019 to be 5.4 million. With the shortage of rental housing needs that are still very large, the development needs of rental flats in the future are still very high. But on the other hand, the implementation of construction projects in Indonesia, in general, the number of work accidents also increased. Referring to Labor Social Service Agency (BPJS) data, nationally the number of occupational accidents in the construction sector is recorded as the most national sector of the number of occupational accidents. Managerial finance is important to assist the process of making decisions related to work safety. While the regulations and provisions concerning occupational, health, and safety (OHS) financing in Indonesia in the construction sector, especially in buildings, have not been clearly and measurably regulated. In its implementation, the existing regulations have not been fully followed by construction actors even within the Ministry of Public Works and Public Housing itself. Architectural works on building construction, in this case, the construction of rental apartments is a job that has the highest number of work items compared to other types of work items. This study resulted in standardized Work Breakdown Structure, safety risks identification, mitigation risks and the component of safety cost for Architectural Works in Rental Apartments Building Construction Project.
\end{abstract}

Index Terms: : Apartments Building, Architectural Works, Safety Cost, Safety Risk, Work Breakdown Structure

\section{INTRODUCTION}

The need for housing is one of the basic needs outside of clothing and food. But in fact, housing in Indonesia still has a supply deficit of 7.6 million in 2015 . The government is targeting a shortage of supplies or a housing backlog in 2019 to 5.4 million. The reduction of 2.2 million housing backlogs is part of the Housing Strategic Plan for 2015-2019 which is divided into two schemes, namely the provision of housing for 850,000 units and housing financing of 1,350,000 units. The Ministry of Public Works and Housing targets the construction of 550,000 rental apartments. The realization of the construction of rental apartments from 2015-2017 was 31,511 units with the shortage of rental housing needs that are still very large, the need for the construction of rental apartments in the future is still very high.

Revised Manuscript Received on April 19, 2019.

Ditto Ferakhim, Civil Engineering, Universitas Indonesia, Depok, Indonesia. (Email: ditto_ferakhim@yahoo.com)

Yusuf Latief, Civil Engineering, Universitas Indonesia, Depok, Indonesia.(Email: yusuflatief73@gmail.com)
But on the other hand, the implementation of construction projects in Indonesia, in general, the number of work accidents also increased. Referring to Labor Social Service Agency (BPJS) data, nationally the number of occupational accidents in the construction sector is recorded as the most national sector of the number of occupational accidents. Work accident cases that occurred in 2016 (until November) recorded 101,367 incidents with 2,382 people died, while in 2015 there were 110,285 people with 2,375 people died. Total work accidents in 2017 were 123 thousand cases with a claim value of IDR 971 billion more. This figure increased from 2016 with a claim value of only IDR 792 billion more. In this regard, since March 2018, 14 cases of workplace accidents have occurred in the past seven months.

The need for housing is one of the basic needs outside of clothing and food. But in fact, housing in Indonesia still has a supply deficit of 7.6 million in 2015 . The government is targeting a shortage of supplies or a housing backlog in 2019 to 5.4 million. The reduction of 2.2 million housing backlogs is part of the Housing Strategic Plan for 2015-2019 which is divided into two schemes, namely the provision of housing for 850,000 units and housing financing of $1,350,000$ units. The Ministry of Public Works and Housing targets the construction of 550,000 rental apartments. The realization of the construction of rental apartments from 2015-2017 was 31,511 units with the shortage of rental housing needs that are still very large, the need for the construction of rental apartments in the future is still very high.

But on the other hand, the implementation of construction projects in Indonesia, in general, the number of work accidents also increased. Referring to Labor Social Service Agency (BPJS) data, nationally the number of occupational accidents in the construction sector is recorded as the most national sector of the number of occupational accidents. Work accident cases that occurred in 2016 (until November) recorded 101,367 incidents with 2,382 people died, while in 2015 there were 110,285 people with 2,375 people died. Total work accidents in 2017 were 123 thousand cases with a claim value of IDR 971 billion more. This figure increased from 2016 with a claim value of only IDR 792 billion more. In this regard, since March 2018, 14 cases of workplace accidents have occurred in the past seven months. 
Making WBS and determining work items appropriately is a useful and necessary effort for effective activity-based risk assessment [1] . The Work Breakdown Structure (WBS) divides the project into several parts to make activities more manageable. Each part is considered a product, so planning, cost estimation, observation, and control can be done through these parts [2]. The WBS provides a foundation for project planning, cost planning, resource scheduling, and allocation, as well as risk management [3]. Furthermore, Park \& Kim (2013) [4] stated that the identification of riskbased activities effectively is one of the most important aspects of planning $\mathrm{OSH}$ management in projects that are successful efficiently.

Every activity that has been grouped in a standard WBS, will be easier to identify potential risks and each project implementer will make a form of risk mitigation from the existing risk source, therefore it is important to develop a standard Work Breakdown Structure for the manufacture of safety plan risk so that the output can be used as a guideline for implementing construction [5].

Architectural work on building construction, in this case, the construction of rental apartments is a job that has the highest number of work items compared to other types of work items. Based on research by G. Emre Gurcanli, Senem Bilir, Merve Sevim (2015) [1], from the analysis of safety main work items in buildings it was found that the number of main work items of the architectural type was the most compared to the main work items of other types, namely 7 out of 14 main works item.

Managerial finance is important to assist the process of making decisions related to work safety [6]. While the regulations and provisions concerning OHS financing in Indonesia in the construction sector, especially in buildings, have not been clearly and measurably regulated. In its implementation, the existing regulations have not been fully followed by construction actors even within the Ministry of Public Works and Public Housing itself. According to Cooper and Kaplan (1992) [7], Activity-Based Costing (ABC) has emerged as a new approach that connects costs directly related to business activities with manufactured products. To make activity-based cost calculations, creating a WBS and determining work items appropriately is a useful and necessary effort for effective activity-based risk assessment [1].

Based on the findings above, given the highly demands for the construction of rental apartments, the high number of occupational accidents and the lack of overall implementation of safety cost financing within the Ministry of Public Works, this study focuses on standardized work breakdown structure, safety risks identification, safety plan and component of safety cost for architectural works in rental apartments building construction project.

\section{LITERATURE REVIEW}

\subsection{Work Breakdown Structure}

According to PMBOK sixth edition [2], the Work Breakdown Structure (WBS) is a hierarchical, deliverable oriented work decomposition to be carried out by the project team to achieve project objectives and produce required deliverables. Deliverable is a unique product, result, or capability to display services that must be produced to complete the process, phase, or project. Often used narrowly in reference to external deliverables, which are subject to approval by the project sponsor or customer. Tonder \& Bekker (2012) [8] also defines deliverables as each measurable, real, verifiable item that must be produced to complement a project or part of a project.

Making WBS itself is the process of deciphering deliverables and project work in the form of individual components in the form of lists that are top-down in nature and hierarchically explain the components that must be built, and work related to them. Each WBS level derivative represents an increasingly detailed project definition. A WBS is a project divider system that can be managed work packages, components, or WBS elements to provide a general framework for scope scheduling, costs, allocation of responsibilities, communication, risk assessment, supervision and control [2]. The approach followed by the project team in developing WBS revolves around the reuse of previous WBS with several changes, to progressive details of the work needed for the project, to the development of deliverable-based WBSs with a focus on the main functionality of the final product [8].

\subsection{Architectural Works}

Architectural work is a work with scope to beautify the appearance of a building without affecting the strength of the building [9]. Some details of the main types of work in architectural work are as follows [10]:

\section{Floor Work}

The floor is the base of a room or building. The main function of the floor is the base of the room that can hold all the loads on it. For the floor, it needs a beautiful, strong coating material and easy installation and maintenance. The building floor can be made from various materials, both from natural materials such as soil, sand, natural stone, marble, granite, wood, etc. and artificial materials such as plaster, concrete, terrazzo, ceramics, carpets, vinyl, etc.

\section{Wall Work}

The walls are part of the building that serves as a separator between the outer room and the inner room, and as a space barrier one with the other room, as well as the load burden on it. Wall materials can come from natural materials such as natural stone, broken stone/stone, etc, as well as artificial materials such as bricks, bricks, bricks, concrete blocks, and light bricks.

\section{3. $\quad$ Ceiling Work}

The ceiling is the upholstery of the upper part of a room. The function of the ceiling of a room is as a barrier to the upper part of the room, to hold or reduce hot air due to radiation that penetrates the roof, confirming the structure of the room or building, hanging lights, and beautifying the room. Ceiling frames are generally made from materials that have light and strong properties such as wood, bamboo, iron / pipe, and aluminum, while ceiling coatings are made of 
materials that are lighter and thinner than frame material such as wooden boards, woven bamboo, plywood, asbestos, soft board, gypsum board, acoustic board, and aluminum.

\section{4. $\quad$ Door and Window Works}

The frame is a part of the wall that serves as aids to form a good relationship between the wall and the door or shutters and is usually installed between wall pairs. In order to be able to receive loads from above and from the side, a tool that can withstand these forces is needed, such as ears / fixed ears, anchor on the frame, and locis / neut (specifically doors)

The door leaf is a vertical plane part of the door that functions as a leaf that can be closed and opened, to connect one room to another.

While shutters are part of the window that functions as a leaf that can close and open to connect the room to the etc.

There is equipment so that doors and windows can be used according to their functions[11], generally consisting of:

- Hinges, mounted on one side that is connected to the frame

- Lock, installed on the other side of the door / window leaf hinges for locking / security functions

- The handle (handle) on the leaf door that is integrated with the key, a separate tone, and on the shutters is a separate part and there is no connection with the slot.

- Other equipment such as the cat's eye on the hotel room door that serves to peek out, door stopper for door restraints when opened, and door closer to make the door always close itself after opening.

\section{5. $\quad$ Sanitaire's Work}

Sanitaire is a clean water disposal equipment in the plumbing system. In simple buildings, plumbing / sanitary ware must meet the needs of residents of buildings, for example, bathroom / toilet facilities. Bathroom amenities can be distinguished from the size of the building and the level of life of its inhabitants. For large buildings that have a higher social level, bathroom amenities include a sink / lavatory, toilet, shower, bathtub, bidet, etc. All of this equipment requires complete water supply and disposal of used water and piping.

\section{Facade Work}

The facade work or the outer shell of the building is an external wall and a no-load buffer as a building constituent which can be classified as follows:

- Stone or brick walls, supported on each floor by the frame structure

- $\quad$ Brick panels or wood frame panels and metal frame panels that support some lightweight panel material.

- $\quad$ Pre-cast concrete panels or plates are hung on the frame

- $\quad$ Curtain wall made of glass and lightweight panels held by a metal frame attached to the outside of the frame.

7. Roof Work outside room, the type can be shuttered outward, alive and dead, the material can be made of wood, PVC plastic, glass,

The roof is an element of a building located at the top of a building. Its main function is as a barrier / protection from the sun's heat, a barrier / protector from rainwater, a protective barrier from gusts of wind, and for the beauty and adjustment of the environment. The material used to make the roof can be made from natural / organic materials, artificial materials such as clay tile, ceramic tile, and concrete, as well as factory-made materials such as zinc, asbestos, plastic, tegola, steel / steel, aluminum, etc.

\section{8. $\quad$ Other Work}

Other work includes all architectural work that has not been listed in the main types of work described previously. Other work generally includes railing work, signage work, crown work, canopy work, skylight work, and other work according to the needs of high-rise design.

The following are WBS standards for architectural work for high-rise building types [10]:

- WBS Framework

- $\quad$ WBS Level 1 Project Name;

- WBS Level 2 Primary Construction Elements; WBS Level 3 Location; WBS Level 4 Job Types / Sub-Elements;

WBS Level 5 Work Package;

Alternative Methods / Designs;

WBS Level 6 Activities;

WBS Level 7 Material, Equipment and Labor

Resources.

- The type of work for architectural work can be divided into:

- Wall Work;

- $\quad$ Floor Work;

- Window Door Works;

- Window Door Hardware Works;

- $\quad$ Sanitaire's Work;

- $\quad$ Facade work;

- $\quad$ Roof work;

- $\quad$ Other work.

- The Work Package for Architectural Works can be divided into:

- $\quad$ Floor Work: Floor; Depreciation

- Wall Work: Walls; Wall Panels; Cubical Toiler Ceiling Work: Ceiling,

Door \& Window Works: Doors; Window Door; Window, Door \& Window Hardware Works: Door Hardware; Window Hardware; Accessories

Sanitaire Work: Toilet Basement Sanitaire; Pantry Sanitaire; Mushala Sanitaire; Public Toilet Sanitaire; Residential Toilet Sanitaire

\section{Facade Work: Walls; Secondary Skin}

- $\quad$ Roof Work: Roof Insulation; Roof Coating; Gutter

- Other Work: Grill; Railing; Canopy; Gutter; Column Cover, Parking Mark Paint; Island Floor Elevation; Wheel Stopper; Corner Guard Column; Convex mirror; Signpost; Croquet Head; Crown.

\subsection{Safety Risk Identification}

Sun Y. et al (2008) [12] selected the four steps for risk 
identification, such as:

1. A framework for the checklist was developed according to sources of risk factors on site safety.

2. Through comprehensive and rigorous literature review. The description of these risks is refined one by one through several rounds of discussions within the research team to ensure explicit and concise statements. Based on the above work, a draft safety risk checklist was established.

3. In depth interviews with industry experts, which consist of senior managers, designer, and project manager construction, a senior official from the health department and top managerial personnel. By consulting with these experts, several new safety risks are identified while the number of risks on the checklist is reduced as some similar risks were merged.

4. Investigation and identifying and discussing the detailed risk with the top management team of each stakeholder.

For this study, the risk identification will be using the second and third method proposed by Sun et al (2008) [12], which are literature review to develop basic safety risks and interview with experts on safety construction field to validate the risks.

\subsection{Safety Plan}

The Safety Plan often referred to as the HSE Plan, is a plan document that contains safety practices that can help companies avoid potential hazards and can control them in the best way when in these hazardous conditions. It's just that the HSE Plan (Health Safety Environment Plan) in addition to considering dangerous conditions for humans also considers the conditions of environmental factors, flora, and fauna around the project to be carried out [13].

In the Ministry of Public Works and Public Housing projects, the Safety Plan is better known as RK3K (Contract Safety Work Plan). RK3K is a complete document of the implementation plan for Construction Safety Management in the Public Works Field and is included with the contract document of a construction work, which is made by the Service Provider and approved by the Service User, which is then used as a means of interaction between Service Providers and Service Users in the implementation of Public Works Construction Safety Management.

The purpose of making a safety plan is [14]:

a. To conduct studies and/or analysis regarding the impact of non-compliance with standards and operating conditions.

b. To get alternative problem solving in order to guarantee the level of operation.

c. To estimate the effectiveness of each alternative solution to safety problems as referred to in letter $\mathrm{b}$ above.

d. To make recommendations for changes or restrictions on operating procedures or capacity restrictions or other matters related to non-compliance with standards and operating conditions.

e. Identify safety targets that must be met to ensure operating safety.

In the safety plan, the standard document created is a document created for work operational safety issues which includes: hazard identification, risk assessment and mitigation measures and conditions that must be met to maintain safety levels [14].

The safety plan program consists of [14]:

\section{Objectives, Targets and Programs:}

What is intended The purpose of the Safety Plan is the purpose of why the Safety Plan is made and what commitments will be achieved by the contractor. Targets to be achieved at the time of project implementation and the end of the project usually include Scoring from Safety Performance Implementation from Safety Aspects and Occupational Health Aspects including safety culture. The program that will be achieved is how to manage occupational safety and health.

\section{2. $\quad$ Risk assessment:}

The process of identifying hazard, analysis, and elimination and/or mitigation at an acceptable level to the risks that threaten project operations. Risk assessment aims to find the balance of the allocation of resources to all risks and their control and mitigation. In risk management, the risk probability and severity/consequences of risk are determined in advance. Hazard is a condition, object or activity that has the potential to cause injury to personnel, equipment or structural damage, material loss or reduced ability to carry out a function. Severity is a possible consequence of a hazard situation, where as a benchmark is the worst possible situation.

\section{Identification of Aspects and Environmental} Impacts

(IADL) is also made, if what is requested by the Owner/Service User is the HSE Plan.

\section{Mitigation:}

An action to eliminate potential hazards or reduce the probability or level of risk. There are 3 strategies in implementing mitigation, namely: the first avoidance, is the operation or activity in the area is canceled because the risk is greater than the profit. The second is a reduction, namely the frequency of operations or activities is reduced, or action is taken to reduce the level of consequences of acceptable risks. While the last is separation, an action taken to isolate the effects of risk or apply layered protection to reduce the level of risk. In mitigation there are 3 defenses that can be applied: 1 . technology, 2. training, and 3 regulations/procedures.

\section{5. $\quad$ Monitoring (monitoring):}

When changes are made by placing these defenses, it must be ensured that these changes do not bring new hazards, and defenses work properly. Monitoring and reviewing is done to see if defenses can actually work so that the probability is reduced.

\section{Conclusion}

\subsection{Safety Cost}

Based on the Regulation [15], safety costs are consist of: 


\section{a. General Safety costs:}

General cost calculations for safety purposes such as Personal Protective Equipment (PPE): helmets, vests, shoes, masks, raincoats, hats, gloves, protective goggles and others have been calculated in the general overhead costs.

\section{b. Specific Safety costs:}

1. For special HSE purposes, for example: diving equipment, acid or other equipment must be accommodated in equipment mobilization (preparation work).

2. Provisions on safety items specifically in the Cipta Karya sector include:

Mobilization: safety personnel, work protective equipment (APK), signs

- $\quad$ Health facilities

- Labor insurance and licensing.

a. Safety Accident Specific Protection Engineering Costs:

1. Specifically for specific protection must be accommodated in Unit Price Analysis Special OHS work that is given a sign (safety) such as to protect labor at the time of excavation requires reinforced excavation walls such as AHSP T.12 (safety).

2. Provision of Unit Price Analysis items Safety work in the Cipta Karya sector includes safety net work.

\section{METHODOLOGY}

In this section explain the approach and methodology used in this study. This can be illustrated by the Fig. 1 as follows:

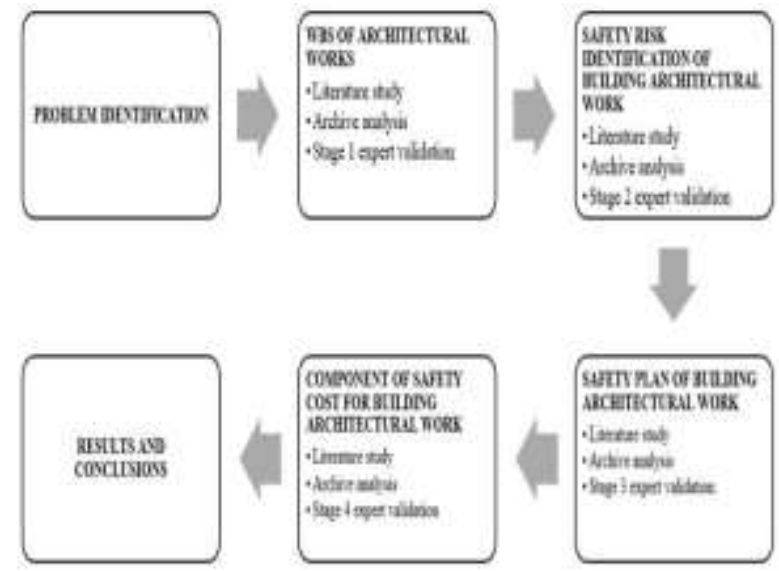

Fig. 1. Research Flow

In the first part of this study, identification of problems that still occur today is related to the conditions presented in the introduction. It was found that there was still a high need for the construction of rented apartments, high rates of accidents in the workplace and low implementation of safety risk management at the Ministry of Public Works and Public Housing. Therefore, more detailed security risk identification with WBS-based is needed. Building

At this stage a literature study was carried out from books, journals and previous research on WBS architectural work in residential buildings. After that, archive analysis

\subsection{Problem Identification}

\subsection{WBS of Architectural Works In Rental Apartments}

was carried out for the construction of rental flats was built and was being built by the Ministry of Public Works and Public Housing. From these two things, a phase 1 questionnaire was made which contained the WBS architectural work of a flat apartment building to be validated to experts.

Validating experts consist of 5 experts in the building project which are shown in Table I, consisting of:

Table I. Expert for Validation Phase 1

\begin{tabular}{|c|c|c|c|c|}
\hline $\begin{array}{c}\text { Expert } \\
s\end{array}$ & Position & Company & $\begin{array}{c}\text { Experi } \\
\text { ences }\end{array}$ & $\begin{array}{c}\text { Academic } \\
\text { Title }\end{array}$ \\
\hline $\begin{array}{l}\text { Expert } \\
1\end{array}$ & $\begin{array}{l}\text { Executiv } \\
\text { e Director }\end{array}$ & $\begin{array}{l}\text { Indonesian } \\
\text { Project } \\
\text { Management } \\
\text { Expert } \\
\text { Association }\end{array}$ & $\begin{array}{l}45 \\
\text { Years }\end{array}$ & $\mathrm{PhD}$ \\
\hline $\begin{array}{l}\text { Expert } \\
2\end{array}$ & $\begin{array}{l}\text { An expert } \\
\text { and an } \\
\text { academic }\end{array}$ & $\begin{array}{l}\text { PT. Yodya } \\
\text { Karya } \\
\text { (Constructio } \\
\text { n } \\
\text { Management } \\
\text { Consultant } \\
\text { Consultant) }\end{array}$ & $\begin{array}{l}40 \\
\text { Years }\end{array}$ & Magister \\
\hline $\begin{array}{l}\text { Expert } \\
3\end{array}$ & $\begin{array}{l}\text { An expert } \\
\text { and an } \\
\text { academic }\end{array}$ & $\begin{array}{l}\text { PT. Gita } \\
\text { Rencana } \\
\text { Multiplan }\end{array}$ & $\begin{array}{l}37 \\
\text { Years }\end{array}$ & $\mathrm{PhD}$ \\
\hline $\begin{array}{l}\text { Expert } \\
4\end{array}$ & $\begin{array}{l}\text { Project } \\
\text { Manager }\end{array}$ & $\begin{array}{l}\text { PT. Wijaya } \\
\text { Karya } \\
\text { (Building } \\
\text { Contractor) }\end{array}$ & $\begin{array}{l}28 \\
\text { Years }\end{array}$ & $\begin{array}{l}\text { Bachelor' } \\
\text { s degree }\end{array}$ \\
\hline $\begin{array}{l}\text { Expert } \\
5\end{array}$ & $\begin{array}{l}\text { Project } \\
\text { Manager }\end{array}$ & $\begin{array}{l}\text { PT. Brantas } \\
\text { Abipraya } \\
\text { (Building } \\
\text { Contractor) }\end{array}$ & $\begin{array}{l}\text { 11Year } \\
\mathrm{s}\end{array}$ & $\begin{array}{l}\text { Bachelor' } \\
\text { s degree }\end{array}$ \\
\hline
\end{tabular}

3.3 Safety Risk Identification of Architectural Works in Rental Apartment Building

At this stage a literature study was carried out from books, journals and previous research on the safety risk of architectural work in residential buildings. Furthermore, a phase 2 questionnaire was made which identified the safety risks of architectural work on a flat apartment building to be validated to experts based on previous validated WBS.

Validating experts consist of 3 experts in the building project which are shown in Table II, consisting of:

Table II. Expert for Validation Phase 2

\begin{tabular}{|c|c|c|c|c|}
\hline $\begin{array}{c}\text { Expert } \\
s\end{array}$ & Position & Company & $\begin{array}{c}\text { Experi } \\
\text { ences }\end{array}$ & $\begin{array}{c}\text { Academic } \\
\text { Title }\end{array}$ \\
\hline $\begin{array}{l}\text { Expert } \\
1\end{array}$ & $\begin{array}{l}\text { Project } \\
\text { Manager }\end{array}$ & $\begin{array}{l}\text { PT. Wijaya } \\
\text { Karya } \\
\text { (Building } \\
\text { Contractor) }\end{array}$ & $\begin{array}{l}28 \\
\text { Years }\end{array}$ & $\begin{array}{l}\text { Bachelor' } \\
\text { s degree }\end{array}$ \\
\hline $\begin{array}{l}\text { Expert } \\
2\end{array}$ & $\begin{array}{l}\text { Building } \\
\text { Division } \\
\text { Operatio } \\
\text { n } \\
\text { Manager } \\
\text { I }\end{array}$ & $\begin{array}{l}\text { PT Ciriajasa } \\
\text { Cipta } \\
\text { Mandiri } \\
\text { (Constructio } \\
\text { n } \\
\text { Management } \\
\text { Consultant) }\end{array}$ & $\begin{array}{l}40 \\
\text { Years }\end{array}$ & Magister \\
\hline $\begin{array}{l}\text { Expert } \\
3\end{array}$ & $\begin{array}{l}\text { Project } \\
\text { Manager }\end{array}$ & $\begin{array}{l}\text { PT. Brantas } \\
\text { Abipraya } \\
\text { (Building } \\
\text { Contractor) }\end{array}$ & $\begin{array}{l}\text { 11Year } \\
\mathrm{s}\end{array}$ & $\begin{array}{l}\text { Bachelor' } \\
\text { s degree }\end{array}$ \\
\hline
\end{tabular}




\subsection{Safety Plan of Architectural Works in Rental} Apartment Building

At this stage a literature study was carried out from books, journals and previous research on the safety risks of architectural work in residential buildings. Furthermore, a phase 3 questionnaire was made which identified the safety plan of architectural work on a flat apartment building to be validated to experts based on previous validated safety risk.

Validating experts consist of 3 experts in the building project which are shown in Table III, consisting of:

Table III. Expert for Validation Phase 3

\begin{tabular}{|c|c|c|c|c|}
\hline $\begin{array}{c}\text { Expert } \\
s\end{array}$ & Position & Company & $\begin{array}{c}\text { Experi } \\
\text { ences }\end{array}$ & $\begin{array}{c}\text { Academic } \\
\text { Title }\end{array}$ \\
\hline $\begin{array}{l}\text { Expert } \\
1\end{array}$ & $\begin{array}{l}\text { Executiv } \\
\text { e Director }\end{array}$ & $\begin{array}{l}\text { Indonesian } \\
\text { Project } \\
\text { Management } \\
\text { Expert } \\
\text { Association }\end{array}$ & $\begin{array}{l}45 \\
\text { Years }\end{array}$ & $\mathrm{PhD}$ \\
\hline $\begin{array}{l}\text { Expert } \\
2\end{array}$ & Lecturer & $\begin{array}{l}\text { University } \\
\text { of Indonesia }\end{array}$ & $\begin{array}{l}40 \\
\text { Years }\end{array}$ & Magister \\
\hline $\begin{array}{l}\text { Expert } \\
3\end{array}$ & $\begin{array}{l}\text { Building } \\
\text { Division } \\
\text { QHSE } \\
\text { Manager } \\
\text {-I }\end{array}$ & $\begin{array}{l}\text { PT. Brantas } \\
\text { Abipraya } \\
\text { (Building } \\
\text { Contractor) }\end{array}$ & $\begin{array}{l}11 \text { Year } \\
\text { s }\end{array}$ & $\begin{array}{l}\text { Bachelor' } \\
\text { s degree }\end{array}$ \\
\hline
\end{tabular}

3.5 Component of Safety Cost for Architectural Works in Rental Apartment Building

At this stage a literature study was carried out from books, journals and previous research on the safety plan of architectural work in residential buildings. Furthermore, a phase 4 questionnaire was made which identified the component of safety cost for architectural work on a flat apartment building to be validated to experts based on previous validated safety plan.

Validating experts consist of 3 experts in the building project which are shown in Table IV, consisting of:

Table IV. Expert for Validation Phase 4

\begin{tabular}{|c|c|c|c|c|}
\hline $\begin{array}{c}\text { Expert } \\
\text { s }\end{array}$ & Position & Company & $\begin{array}{c}\text { Experi } \\
\text { ences }\end{array}$ & $\begin{array}{c}\text { Academic } \\
\text { Title }\end{array}$ \\
\hline $\begin{array}{l}\text { Expert } \\
1\end{array}$ & $\begin{array}{l}\text { Executiv } \\
\text { e Director }\end{array}$ & $\begin{array}{l}\text { Indonesian } \\
\text { Project } \\
\text { Management } \\
\text { Expert } \\
\text { Association }\end{array}$ & $\begin{array}{l}45 \\
\text { Years }\end{array}$ & $\mathrm{PhD}$ \\
\hline $\begin{array}{l}\text { Expert } \\
2\end{array}$ & Lecturer & $\begin{array}{l}\text { University } \\
\text { of Indonesia }\end{array}$ & $\begin{array}{l}40 \\
\text { Years }\end{array}$ & Magister \\
\hline $\begin{array}{l}\text { Expert } \\
3\end{array}$ & $\begin{array}{l}\text { Building } \\
\text { Division } \\
\text { QHSE } \\
\text { Manager } \\
\text {-I }\end{array}$ & $\begin{array}{l}\text { PT. Brantas } \\
\text { Abipraya } \\
\text { (Building } \\
\text { Contractor) }\end{array}$ & $\begin{array}{l}\text { 11Year } \\
\mathrm{s}\end{array}$ & $\begin{array}{l}\text { Bachelor' } \\
\text { s degree }\end{array}$ \\
\hline
\end{tabular}

\section{RESULTS AND DISCUSSION}

\subsection{Standardized Work Breakdown Structure}

The standardized work breakdown structure of architectural works on a flat apartment building can be shown the validated results in Figure 2 below:

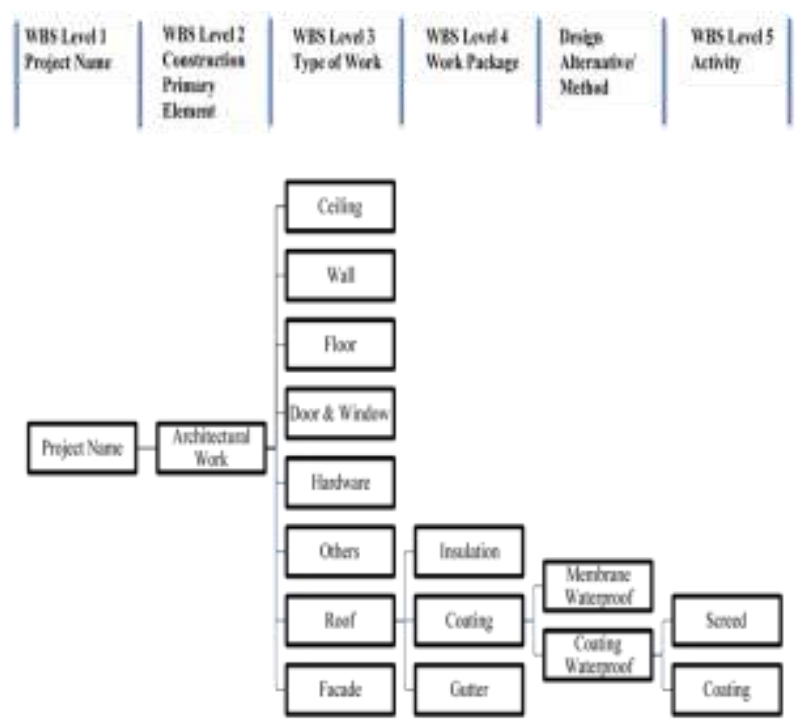

Fig. 2. Standardized Work Breakdown Structure of Architectural Work

a. WBS Level 1 is the Name of the Project

b. WBS Level 2 is the Construction Primary Element

c. WBS Level 3 is the Type of Work consists of 8 elements.

d. WBS Level 4 is the Work Package consists of 32 elements.

e. Design Alternative/Method consitsts of 89 elements.

f. WBS Level 5 is the Activity consist of 264 elements.

The standardized work breakdown structure given above will be used as a guidance to identify the safety risks of architectural works on a flat apartment building.

\subsection{Safety Risk Identification}

From previous WBS, there are 12 potential safety risks that have been validated for architectural works on a flat apartment building:

1. Falling from a height

2. Struck, because of objects that fall / move etc.

3. Hit, contact with sharp objects / hard objects

4. Suction / absorption of harmful substances into the body, through breathing / skin

5. Slipped

6. Exposed to electric current

7. Movement exceeds ability (dislocated)

8. The eye is exposed to sprays

9. Caught on and between objects (sandwiched, buried, drowned, etc.)

10. Exposed (temperature, air pressure, vibration, radiation, sound, light, etc.)

11. Fire Hazard

12. Overload of Vertical Transport Equipment.

The Table $\mathrm{V}$ shown below is an example results of risk identification based on architectural works WBS activities on a flat apartment building: 
Table V. Risk Identification

\begin{tabular}{|c|c|}
\hline $\begin{array}{l}\text { WBS Level } 5 \\
\text { Activity }\end{array}$ & Safety Risk \\
\hline \multicolumn{2}{|c|}{$\begin{array}{l}\text { Work Package: Ceiling; Method: Exposed Concrete } \\
\text { Ceiling Finishing }\end{array}$} \\
\hline \multirow[t]{3}{*}{ Surface leveling } & $\begin{array}{l}\text { Falling from a } \\
\text { height }\end{array}$ \\
\hline & $\begin{array}{l}\text { Hit, contact with } \\
\text { sharp objects / hard } \\
\text { objects }\end{array}$ \\
\hline & $\begin{array}{l}\text { Movement exceeds } \\
\text { ability (dislocated) }\end{array}$ \\
\hline \multirow[t]{3}{*}{ Painting } & $\begin{array}{l}\text { Falling from a } \\
\text { height }\end{array}$ \\
\hline & $\begin{array}{l}\text { Suction / } \\
\text { absorption of } \\
\text { harmful substances } \\
\text { into the body, } \\
\text { through breathing / } \\
\text { skin }\end{array}$ \\
\hline & $\begin{array}{l}\text { The eye is exposed } \\
\text { to sprays }\end{array}$ \\
\hline
\end{tabular}

Work Package: Ceiling; Method: Interior Gypsum Ceiling

\begin{tabular}{ll}
\hline Frame installation & $\begin{array}{l}\text { Falling from a } \\
\text { height }\end{array}$ \\
& $\begin{array}{l}\text { Struck, because of } \\
\text { objects that fall / } \\
\text { move etc. }\end{array}$ \\
& $\begin{array}{l}\text { Hit, contact with } \\
\text { sharp objects / hard } \\
\text { objects }\end{array}$ \\
\hline $\begin{array}{l}\text { Exposed to electric } \\
\text { current }\end{array}$ \\
\hline
\end{tabular}

\begin{tabular}{ll}
\hline $\begin{array}{l}\text { WBS Level 5 } \\
\text { Activity }\end{array}$ & Safety Risk \\
\hline $\begin{array}{l}\text { The eye is exposed } \\
\text { to sprays } \\
\text { installation }\end{array}$ & $\begin{array}{l}\text { Falling from a } \\
\text { height }\end{array}$ \\
\cline { 2 - 2 } & $\begin{array}{l}\text { Exposed to electric } \\
\text { current }\end{array}$ \\
\hline & $\begin{array}{l}\text { The eye is exposed } \\
\text { to sprays }\end{array}$ \\
\hline Painting & $\begin{array}{l}\text { Falling from a } \\
\text { height }\end{array}$ \\
& $\begin{array}{l}\text { Suction } \\
\text { absorption } \\
\text { harmful substances } \\
\text { into the body, } \\
\text { through breathing / } \\
\text { skin }\end{array}$ \\
\hline $\begin{array}{l}\text { The eye is exposed } \\
\text { to sprays }\end{array}$ \\
\hline
\end{tabular}

\subsection{Safety Plan}

From previous safety risk identification, Table VI shows the validated safety plan of architectural works on a flat apartment building, for every safety risk that have been identified before:

Table VI. Safety Plan

\section{No Potential Safety Risk for Safety Risk Control Hierarchy of Controls
Architectural Work}

$1 \quad$ Falling from a height Available workbenches / platforms Engineering

that are strong and wide

\begin{tabular}{ll}
\hline Making safety fence & Engineering \\
\hline Making horizontal safety nets & Engineering \\
\hline Enough lighting in the opening area & Engineering \\
\hline Install signs "Beware of Falling" & Administrative \\
\hline Hold the Tool Box Meeting & Administrative \\
\hline $\begin{array}{l}\text { A body line is available to connect } \\
\text { the body harness }\end{array}$ & Engineering \\
\hline $\begin{array}{l}\text { Use a safety belt / safety body } \\
\text { harness when working - PPE }\end{array}$ & PPE \\
$\begin{array}{l}\text { Material handling and binding is } \\
\text { done carefully }\end{array}$ & Engineering \\
\hline
\end{tabular}

Struck, because of objects that fall / move etc.
Using radio communication devices Administrative

Install signs "Beware of Material Administrative Falling" 


\section{No}

Potential Safety Risk for Architectural Work

Safety Risk Control

Hierarchy of Controls

\begin{tabular}{|c|c|c|c|}
\hline & & $\begin{array}{l}\text { Using Standard PPE (Helmet, Vest } \\
\text { and Shoes) }\end{array}$ & PPE \\
\hline \multirow[t]{3}{*}{3} & \multirow[t]{3}{*}{$\begin{array}{l}\text { Hit, contact with sharp objects } \\
\text { / hard objects }\end{array}$} & Install "Be careful" signs & Administrative \\
\hline & & Hold the Tool Box Meeting & Administrative \\
\hline & & Use gloves when working & PPE \\
\hline \multirow[t]{4}{*}{4} & \multirow[t]{4}{*}{$\begin{array}{l}\text { Suction / absorption of } \\
\text { harmful substances into the } \\
\text { body, through breathing / skin }\end{array}$} & $\begin{array}{l}\text { Dangerous and Toxic Goods is } \\
\text { placed in a special area and } \\
\text { separated from non- Dangerous and } \\
\text { Toxic Goods material. }\end{array}$ & Engineering \\
\hline & & $\begin{array}{l}\text { Handling of Dangerous and Toxic } \\
\text { Goods material in accordance with } \\
\text { MSDS (Materials Safety Data Sheet) }\end{array}$ & Administrative \\
\hline & & Use gloves when working & PPE \\
\hline & & Use a mask while working & PPE \\
\hline \multirow[t]{3}{*}{5} & \multirow[t]{3}{*}{ Slipped } & $\begin{array}{l}\text { Material placement is neat and there } \\
\text { is access to people's roads }\end{array}$ & Engineering \\
\hline & & $\begin{array}{l}\text { Creating 5R (Compact, Neat, } \\
\text { Refreshing, Caring and Diligent) } \\
\text { conditions in the environment }\end{array}$ & Engineering \\
\hline & & Install "Be careful" signs & Administrative \\
\hline \multirow[t]{10}{*}{6} & \multirow[t]{10}{*}{ Exposed to electric current } & $\begin{array}{l}\text { Avoid the many flow distribution } \\
\text { connections }\end{array}$ & Engineering \\
\hline & & $\begin{array}{l}\text { Giving security insulation on the } \\
\text { chipped cable }\end{array}$ & Engineering \\
\hline & & $\begin{array}{l}\text { Electrical connection is coordinated } \\
\text { with an electrician }\end{array}$ & Engineering \\
\hline & & Prevent / avoid puddles & Engineering \\
\hline & & $\begin{array}{l}\text { Make sure the cable has been hung, } \\
\text { not sticking to the floor, especially } \\
\text { the wet one }\end{array}$ & Engineering \\
\hline & & $\begin{array}{l}\text { Make sure the cable usage is } \\
\text { adjusted to the power capacity }\end{array}$ & Engineering \\
\hline & & $\begin{array}{l}\text { Make sure the electrical connection } \\
\text { uses a socket and is connected to the } \\
\text { specified panel }\end{array}$ & Engineering \\
\hline & & Install "Electricity Hazard" signs & Administrative \\
\hline & & $\begin{array}{l}\text { Periodic checks for electrical } \\
\text { installations }\end{array}$ & Administrative \\
\hline & & Wear rubber gloves and safety shoes & PPE \\
\hline \multirow[t]{5}{*}{7} & \multirow{5}{*}{$\begin{array}{l}\text { Movement } \\
\text { (dislocated) }\end{array}$} & Use carts for material transport & Substitution \\
\hline & & $\begin{array}{l}\text { Do not transport material beyond the } \\
\text { load carrying cart }\end{array}$ & Administrative \\
\hline & & Install "ergonomic" signs & Administrative \\
\hline & & $\begin{array}{l}\text { Material lifting does not exceed the } \\
\text { burden of people }\end{array}$ & Administrative \\
\hline & & Handling is done in the right position & Administrative \\
\hline \multirow[t]{4}{*}{8} & \multirow[t]{4}{*}{ The eye is exposed to sprays } & $\begin{array}{l}\text { Keeping the distance safe from being } \\
\text { spattered }\end{array}$ & Administrative \\
\hline & & Install "communication" signs & Administrative \\
\hline & & Using safety googles & PPE \\
\hline & & Using a face shield & PPE \\
\hline
\end{tabular}




\begin{tabular}{|c|c|c|c|}
\hline No & $\begin{array}{l}\text { Potential Safety Risk for } \\
\text { Architectural Work }\end{array}$ & Safety Risk Control & Hierarchy of Controls \\
\hline \multirow[t]{2}{*}{9} & \multirow[t]{2}{*}{$\begin{array}{l}\text { Caught on and between } \\
\text { objects (sandwiched, buried, } \\
\text { drowned, etc.) }\end{array}$} & $\begin{array}{l}\text { Using Standard PPE (Helmet, Vest } \\
\text { and Shoes) }\end{array}$ & PPE \\
\hline & & Wear gloves when working & PPE \\
\hline \multirow[t]{3}{*}{10} & \multirow{3}{*}{$\begin{array}{l}\text { Exposed (temperature, air } \\
\text { pressure, vibration, radiation, } \\
\text { sound, light, etc.) }\end{array}$} & $\begin{array}{l}\text { Noise measurements were carried } \\
\text { out }\end{array}$ & Engineering \\
\hline & & $\begin{array}{lll}\begin{array}{l}\text { Vibration } \\
\text { carried out }\end{array} & & \text { weasurements } \\
\end{array}$ & Engineering \\
\hline & & Using ear protectors & PPE \\
\hline \multirow[t]{4}{*}{11} & \multirow[t]{4}{*}{ Fire Hazzard } & $\begin{array}{l}\text { An adequate fire extinguisher is } \\
\text { available }\end{array}$ & Administrative \\
\hline & & Fire hazard warning signs & Administrative \\
\hline & & $\begin{array}{l}\text { Handling of Dangerous and Toxic } \\
\text { Goods material in accordance with } \\
\text { the MSDS }\end{array}$ & Administrative \\
\hline & & $\begin{array}{l}\begin{array}{l}\text { Conduct emergency } \\
\text { simulations }\end{array} \\
\text { simponse } \\
\end{array}$ & Administrative \\
\hline \multirow[t]{4}{*}{12} & \multirow{4}{*}{$\begin{array}{l}\text { Overload of Vertical Transport } \\
\text { Equipment }\end{array}$} & Initial load test & Administrative \\
\hline & & Check equipment regularly & Administrative \\
\hline & & $\begin{array}{l}\text { Make sure the safety device (alarm) } \\
\text { is functioning properly }\end{array}$ & Administrative \\
\hline & & Installation of maximum load signs & Administrative \\
\hline
\end{tabular}

We can make the example of safety plan for every activity from architectural WBS based on validated safety control as shown in Table VII below:

Table VII. Example of Safety Plan for One of the Activities from architectural WBS

\begin{tabular}{lll}
\hline WBS Level 5 & Safety Risk & Safety Risk Control \\
Activity &
\end{tabular}

Work Package: Ceiling; Method: Exposed Concrete Ceiling Finishing

Surface levelling Falling from a height

Install signs "Beware of Falling"

Available workbenches / platforms that are strong and wide

Making safety fence

Making horizontal safety nets

Enough lighting in the opening area

A body line is available to connect the body harness

Use a safety belt / safety body harness when working - PPE

Hold the Tool Box Meeting

Hit, contact with sharp Use gloves when working

objects / hard objects $\quad$ Install "Be careful" signs

Hold the Tool Box Meeting

Movement exceeds ability Use carts for material transport

(dislocated) $\quad$ Do not transport material beyond the load carrying cart

Install "ergonomic" signs

Material lifting does not exceed the burden of people

Handling is done in the right position

Painting $\quad$ Falling from a height

Install signs "Beware of Falling"

Available workbenches / platforms that are strong and wide

Making safety fence

Making horizontal safety nets

Enough lighting in the opening area 


\begin{tabular}{|c|c|c|}
\hline $\begin{array}{l}\text { WBS Level } 5 \\
\text { Activity }\end{array}$ & Safety Risk & Safety Risk Control \\
\hline & & A body line is available to connect the body harness \\
\hline & & Use a safety belt / safety body harness when working - PPE \\
\hline & & Hold the Tool Box Meeting \\
\hline & \multirow[t]{3}{*}{$\begin{array}{l}\text { Suction / absorption of } \\
\text { harmful substances into the } \\
\text { body, through breathing / } \\
\text { skin }\end{array}$} & $\begin{array}{l}\text { Dangerous and Toxic Goods is placed in a special area and separated } \\
\text { from non- Dangerous and Toxic Goods material. Handling of } \\
\text { Dangerous and Toxic Goods material in accordance with MSDS } \\
\text { (Materials Safety Data Sheet) }\end{array}$ \\
\hline & & Use gloves when working \\
\hline & & Use a mask while working \\
\hline
\end{tabular}

\begin{tabular}{ll} 
The eye is exposed to sprays & Using safety googles \\
\cline { 2 - 2 } & Using a face shield \\
\hline Keeping the distance safe from being spattered \\
\hline Install "communication" signs
\end{tabular}

\subsection{Cost of Safety}

The safety cost component is calculated based on the hierarchy of safety risks handling controls, as follows:

1. Cost of elimination controls;

2. Cost of substitution controls;

3. Cost of engineering controls;

4. Cost of administrative controls;

5. Cost of Personal Protective Equipment controls.

From this study, the cost of elimination control cannot be defined, because it really depends on the target output and the term of reference of the project. For the cost of substitution controls and the cost of engineering controls are shown in the Table VIII below.

The results of expert validation obtained that for administrative control is divided into two, namely:

1. General Administrative Controls, which are administrative controls that are always held without relying directly on the activities of the WBS. General Administrative Controls consists of:

a. Contract safety plan preparations:

- Making Manuals, Procedures, Work Instruction, Work Permits and Forms

b. Safety socializations and promotions:

- $\quad$ Safety Induction

- $\quad$ Safety Briefing

- $\quad$ Safety Talk and/or Tool Box Meeting

- $\quad$ Safety Training

- Safety Simulation

- Banner

- Poster

- $\quad$ Safety Information Board

c. Worker Insurances and Licenses

- License for Approval of Occupational Safety and Health Development Committee (P2K3)

d. Safety Personnel:

- $\quad$ Safety Expert and Safety Officer

- $\quad$ Emergency Response Officer

- $\quad$ First Aid Officer

- Traffic Controller

- Medical Officer

e. Health Facilities

\section{First aid kit}

$\begin{array}{ll}\text { - } & \text { First aid room } \\ \text { - } & \text { Fogging Equipment } \\ \text { - } & \text { Fogging Medicine } \\ \text { - } & \text { Initial Medical Check Up } \\ \text { - } & \text { Larvaciding abate } \\ \text { f. } & \text { Others } \\ \text { - } & \text { Safety Flag } \\ \text { - } & \text { Evacuation Route } \\ \text { - } & \text { Emergency Lamp } \\ \text { - } & \text { Inspection and Internal Audit Program } \\ \text { - } & \text { Incident Reporting and Investigation } \\ \text { - } & \text { Periodic reports related to Safety }\end{array}$

2. Specific Administrative Controls, which are administrative controls held related to activities on the WBS.

Likewise, the results of expert validation for PPE (Personal Protective Equipment) controls cost is divided into two, namely

1. Standard PPE, which must always be used by anyone in the project area. Standard PPE consists of Safety Helmet, Safety Shoes and Safety Vest.

2. Specific PPE, which is the PPE used, is related to activity on the WBS.

The cost of safety for substitution controls safety risk and engineering controls safety risk are shown in Table VIII. The cost of specific administrative control and cost of specific PPE controls are shown in the Table IX below.

The development of the safety cost component uses the format given from The Regulation of the Minister of Public Works and Public Housing 28/PRT/M/2016. After safety plan is determined, the next step is to make objectives and programs of each safety control risk. The objective explains about the description and measurement, while the program explains resources, duration, achievement indicator, monitoring and person in charge.

After that, the safety cost component of each activity from the work breakdown structure is determined. Table $\mathrm{X}$ below is an example of the results from one of the activities 


\section{v. CONCLUSION}

This study proposed an approach to estimate safety cost for architectural in rental apartments building construction project based on Work Breakdown Structure. Toward this purpose, architectural works WBS for apartments building is developed, a safety risk is identified, a safety plan is developed and finally, the components cost of safety for architectural works is determined.

From the results, the components cost of safety for architectural works can be determined in Fig. 3 as follows

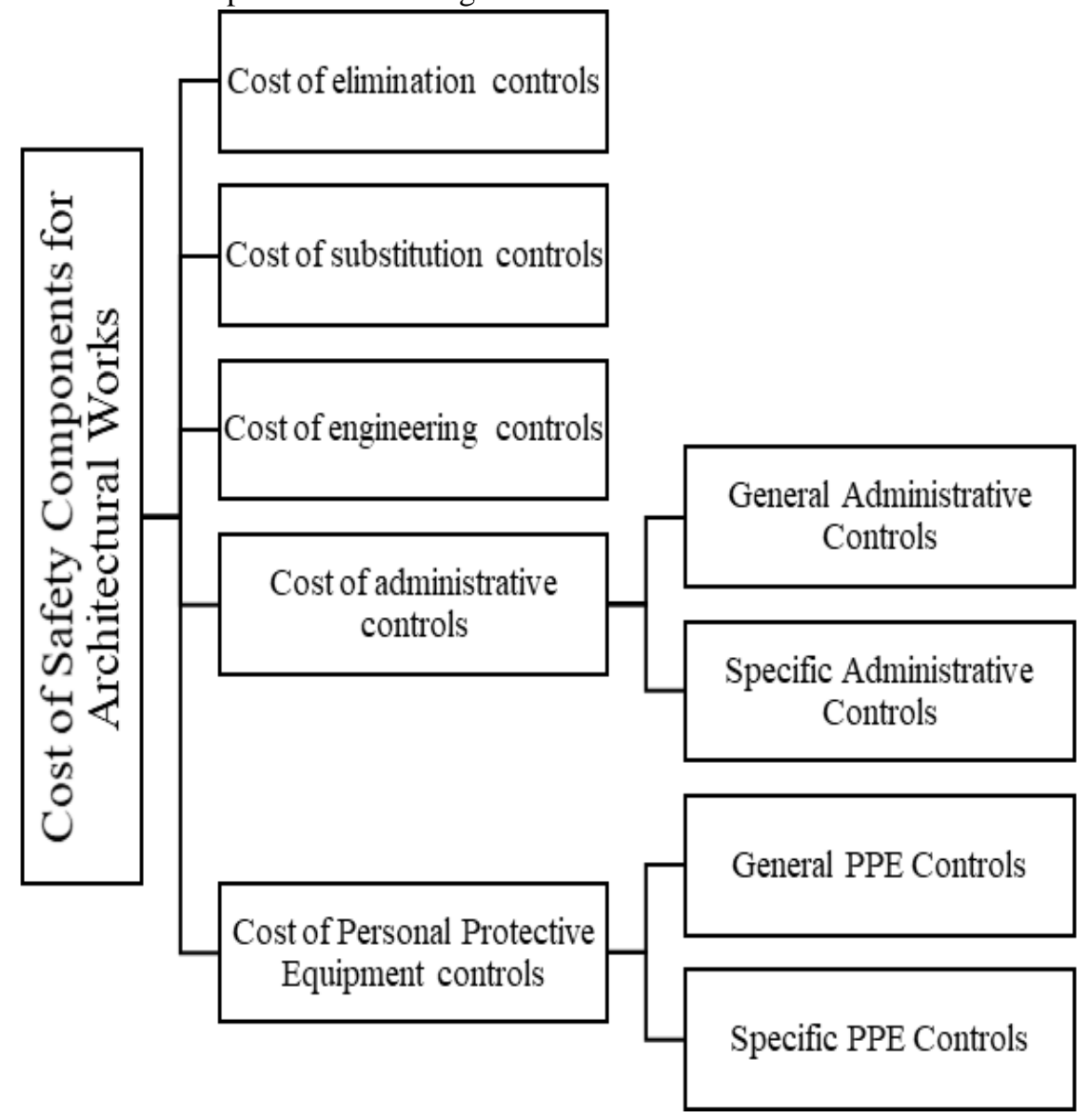

Fig. 3. Cost of Safety Components for Arcthitectural Works

In future research, similar research can be done with different types of construction projects. The limitation of this study is the safety costs calculation is calculated based on price assumptions, not real market price. This study helps to plan safety costs more accurate so the safety performance can be improved.

\section{ACKNOWLEDGMENT}

The Authors would like to thank the financial support provided by Universitas Indonesia through PIT 9 funding scheme under Grant number NKB 0087/UN2.R3.1/HKP.05.00/2019 managed by the Directorate for Research and Public Services (DRPM) Universitas Indonesia.

\section{REFERENCES}

1. Gurcanli, G.E., S. Bilir, and M. Sevim, Activity based risk assessment and safety cost estimation for residential building construction projects. Safety Science, 2015. 80: p. $1-12$.

2. PMI, A guide to the project management body of knowledge (PMBOK guide). 6th ed. 2017: Project Management Institute, Inc.

3. Devi, T.R. and V.S. Reddy, Work breakdown structure of the project. Int J Eng Res Appl, 2012. 2(2): p. 683-686.
4. Park, C.-S. and H.-J. Kim, A framework for construction safety management and visualization system. Automation in Construction, 2013. 33: p. 95-103.

5. Elsye, V., Y. Latief, and L. Sagita, Development of Work Breakdown Structure (WBS) Standard for Producing the Risk Based Structural Work Safety Plan Of Building. MATEC Web Conf., 2018. 147.

6. Ibarrondo-Dávila, M.P., M. López-Alonso, and M.C. Rubio-Gámez, Managerial accounting for safety management. The case of a Spanish construction company. Safety Science, 2015. 79: p. 116-125.

7. Cooper, R. and R.S. Kaplan, Activity-based systems: Measuring the costs of resource usage. Accounting horizons, 1992. 6(3): p. 1-13.

8. Tonder, J.V. and M. Bekker. Analysis of a Methodology to Obtain a Work Breakdown Structure Built Up From Interdependent Key Project Deliverable Packages. 2002.

9. Prasetyo, I.P., Analisis Keterlambatan dan Kualitas Hasil Pekerjaan pada Proyek Konstruksi. 2012, Universitas Indonesia.

10. Rianty, M., Pengembangan Standar WBS (Work Breakdown Structure) untuk Perencanaan Kualitas Pekerjaan Arsitektur Bangunan Tinggi Berbasis Risiko, in Civil Engineering. 2017, Universitas Indonesia. 
11. Tangoro, D., S. Somaatmadja, and K. \& Sukardi, Teknologi Bangunan. 2007.

12. Sun, Y., et al., Safety Risk Identification and Assessment for Beijing Olympic Venues Construction. Journal of Management in Engineering, 2008. 24(1): p. 40-47.

13. . 2015

14. Elsye, V., Pengembangan Standar WBS (Work Breakdown Structure) untuk Pembuatan Safety Plan Pekerjaan Struktur Bangunan Gedung Berbasis Risiko, in Civil Engineering. 2017, Universitas Indonesia.

15. PUPR, Pedoman Sistem Manajemen Keselamatan dan Kesehatan Kerja (SMK3) Konstruksi Bidang Pekerjaan Umum, I.M.o.P.W.a.P. Housing, Editor. 2014, Minister of Public Works and Public Housing: Indonesia. 